\title{
APPLICATION OF A DYNAMIC ENERGY BUDGET MODEL TO MYTILUS EDULIS (L.)
}

\author{
R.J.F. VAN HAREN* and S.A.L.M. KOOIJMAN \\ Free University, Faculty of Biology, De Boelelaan 1087, 1081 HV Amsterdam, the Netherlands
}

\begin{abstract}
Filtering, ingestion, assimilation respiration, growth and reproduction of the blue mussel Mytilus eduIis were successfully described in terms of a dynamic energy budget (DEB) model, which previously had been applied successfully to a variety of other species. The relation between oxygen consumption rate and ingestion rate could be derived from elementary model assumptions. Parameters of the DEB model, estimated for laboratory situations, were applied to field data. The varying growth rates in the field could be described by taking account of changes in food density and quality, and temperature, on the basis of the Arrhenlus relation. A methodology is given to reconstruct ambient food densities from observed growth curves. This can be used to assess the nutritive value of measured substances such as POM or chlorophyll. The concept Scope For Growth is discussed and interpreted in terms of the DEB model. The energy conductance is found to be $0.36 \mathrm{~mm} \cdot \mathrm{d}^{-1}$ at $20^{\circ} \mathrm{C}$, which is close to the mean of many species: $0.43 \mathrm{~mm} \cdot \mathrm{d}^{-1}$.
\end{abstract}

\section{INTRODUCTION}

The dynamics of the energy budget of Mytilus edulis (L.) are of interest for several reasons. It is an important species in estuarine environments, which calls for a close analysis of its role in terms of energetics. It is commercially valuable, so it is useful to elaborate harvesting programmes that can be maintained for long periods. The species is also used as a monitor organism for environmental pollution. The uptake and elimination behaviour of xenobiotics, especially the lipophilic ones such as PCB's, depends on feeding conditions, and so on energetics (KOOIJMAN \& VAN HAREN, 1990). Results of environmental monitoring programmes such as the 'Mussel Watch programme' (GOLDBERG, 1975; PHILLIPS \& RAINBOW, 1988; BAYNE, 1989) are therefore difficult to interpret without a toxico-kinetic model based on physiology which can handle fluctuating conditions in the environment.

Modelling physiological energetics in $M$. edulis is usually based on the widely applied Scope For Growth (SFG) concept and allometric relations between body size and physiological rates (BAYNE, 1976; BAYNE \& NEWELL, 1983; VERHAGEN, 1983; BARETTA \& RUARDIJ, 1988; KLEPPER, 1989). The SFG concept is based on the energy balance of a mussel in steady state conditions. The amount of energy gained by the individual under such conditions equals the amount of energy lost due to maintenance, growth and reproduction. The SFG is the difference between energy gained by feeding and energy lost by respiration (supposedly a measure of maintenance). When this difference is positive, energy is available for growth and reproduction, when it is negative, there is a (dry) weight loss due to the utilization of energy reserves (BAYNE \& NEWELL, 1983). One problem with this approach is that it does not distinguish storage of energy reserves (i.e. lipids, glycogen) from 'structural biomass' in its standardization for body weight.

The necessity to distinguish energy reserves from structural biomass is particularly felt in modelling seasonal variations of body composition. At reproduction mussels experience a dramatic drop in lipid content. Size increase of lipid-rich biomass obviously costs much more energy than of lipid-poor biomass. This type of qualitative difference can only be modelled by separating storage from structural biomass.

The basic difference between 'structural biomass' and storage is that storage materials do not require maintenance and are readily available for use for maintenance, growth and reproduction (KOOIJMAN, 1986c). This is most easily illustrated by a freshly produced egg, which consists of a relatively large amount of energy reserves and an infinitesimally small amount of structured body mass. As is shown for the pond snail Lymnaea stagnalis (L.), such an egg hardly respires (HORSTMANN, 1958). Structural biomass on the other hand does require maintenance, i.e. energy used for recycling of proteins, regulation of chemical composition and circulation. It is not as readily available as an energy source for production. Another problem in the application of SFG 
concerns the interpretation of respiration rates. Although measurements of the energy balance of a particular individual take such a short time that the change in size is negligibly small, the energy invested in growth can be substantial (WIDDOWS \& HAWKINS, 1989; JØRGENSEN, 1990). So part of the respiration measured with a standard conversion to energy is connected with growth, while in the SFG, it is fully assigned to maintenance. This problem can be solved by using a dynamic energy budget (DEB) model, which considers an individual as an input-output system with size and stored energy as state variables.

The present paper shows how the DEB model can be applied to $M$. edulis under submerged conditions. The anaerobic metabolism of littoral individuals is not considered. Originally, the model was developed for Daphnia magna Straus (KOOIJMAN, 1986a; EVERS \& KOOIJMAN, 1989) and successtully applied to $L$. stagnalis (ZONNEVELD \& KOOLJMAN, 1989) and microorganisms (KOOLJMAN et al., 1991). It permits the description of embryo development (KOOIJMAN, 1986c; 2ONNEVELD \& KOOIJMAN, 1993), growth (KOOIJMAN, 1988) and body size scaling relations (KOOIJMAN, 1986b, 1988). ROSS \& NISBET (1990) argued that it is necessary to modify the model to obtain consistency with published data on mussel physiology. We re-analysed these data and used additional ones to test the unmodified DEB model. We will first present a brief description of the model and consider the different processes which are relevant for the energetics. Subsequently we will test it against data from the literature and some unpublished data.

\section{THE DEB MODEL}

We will restrict the present discussion to the feeding stages, which can be split into a juvenile stage that cannot reproduce and an adult one. In these stages, the mussel does not change its shape to any significant extent. The chemical composition of the structural biomass and of stored materials is taken to be constant, so homeostasis is assumed for structural biomass as well as stored materials. Since the composition of stored materials will differ from that of structural biomass, and the storage density can fluctuate, homeostasis is not assumed for the combination of structural biomass and stored materials. A list of frequently used symbols is given in Table 1

Two state variables, volume, $V$ (length ${ }^{3}$ ), and storage, $E$ (energy) are distinguished. The choice for storage as a state variable is motivated by the observation that animals undergoing a sharp change in food density adapt only gradually to a new growth rate. This implies that there is an energy buffer (KOOIJMAN, 1986a); see also the section on growth.

TABLE 1

Variables, primary and compound parameters.

\begin{tabular}{|c|c|c|}
\hline symbol & dimension & interpretation \\
\hline \multicolumn{3}{|c|}{ variables } \\
\hline$t$ & time & time \\
\hline$x$ & weight-length ${ }^{-3}$ & food density \\
\hline$\checkmark$ & length ${ }^{3}$ & body volume \\
\hline$E$ & energy & energy storage \\
\hline$e$ & energy.length ${ }^{-3}$ & scaled energy storage density: $E /\left[E_{m}\right] V$ \\
\hline$R_{c}$ & energy & cumulated energy investment into reproduction \\
\hline \multicolumn{3}{|c|}{ primary parameters } \\
\hline$V_{b}$ & length ${ }^{3}$ & volume at birth \\
\hline$v_{i}$ & length ${ }^{3}$ & volume at start reproductive stage \\
\hline$K$ & weight.length ${ }^{3}$ & saturation constant \\
\hline$\left\{F_{m}\right\}$ & length ${ }^{3} \cdot$ length $^{-2} \cdot$ time $^{-1}$ & maximum surface area-specific filtration rate \\
\hline$\left\{I_{m}\right\}$ & weight length ${ }^{-2} \cdot$ time $^{-1}$ & maximum surface area-specific ingestion rate \\
\hline$\left\{A_{m}\right\}$ & energy.length ${ }^{-2} \cdot$ time $^{-1}$ & maximum surface area-specific assimilation rate \\
\hline$\left[E_{m}\right]$ & energy.length ${ }^{-3}$ & maximum storage density \\
\hline$[M]$ & energy. length ${ }^{-3} \cdot$ time $^{-1}$ & volume-specific maintenance costs per unit of time \\
\hline [G] & energy.length ${ }^{-3}$ & volume-specific costs for growth \\
\hline$\kappa$ & & fraction of utilized energy spent on maintenance plus growth \\
\hline$d_{m}$ & & shape coefficient \\
\hline \multicolumn{3}{|c|}{ compound parameters } \\
\hline$v$ & length.time ${ }^{-1}$ & energy conductance: $\left\{A_{m}\right\} /\left[E_{m}\right]$ \\
\hline$m$ & time $^{-1}$ & maintenance rate constant: $[M] / G]$ \\
\hline$g$ & & energy investment ratio: $[G] / k\left[E_{m}\right]$ \\
\hline
\end{tabular}


Uptake is assumed to follow a type II Holling functional response and is taken proportional to surface area (of the filtering apparatus and/or gut), so the ingestion rate is

$$
I=\left\{I_{m}\right\} V^{2 / 3} \text { with } f=X /(K+X)
$$

where $X$ is the food density, $K$ the saturation constant and $\left\{I_{m}\right\}$ the maximum surface area-specific ingestion rate. The filtering rate is $F=1 / X$, on the assumption that there is complete retention of particles. The maximum filtering rate is thus $V^{2 / 3}\left\{I_{m}\right\} / K$. If the digestive system remains filled with processed food, and has a capacity of $V_{g}$ the gut passage time is $V_{g} / /$ (EVERS \& KOOIJMAN, 1989). The food-energy conversion is taken to be constant, $\left\{A_{m}\right\} /\left\{I_{m}\right\}$, so the assimilation energy, i.e. the total energy input, equals $\left\{A_{m}\right\} N^{2 / 3}$, where $\left\{A_{m}\right\}$ is the maximum surface area-specific assimilation rate. The incoming energy adds to the reserves. When expressed as density, $[E]=E / V$, so energy reserve per volume of body, the reserves follow a first order process. From the assumption of homeostasis for energy reserves it follows that the energy reserves in equilibrium are independent of the length of the mussel i.e.

$$
\frac{d e}{d t}=v V^{-1 / 3}(f-e)
$$

where $e=[E] /\left[E_{m}\right]$, where $\left[E_{m}\right]$ is the maximum storage density and $v=\left\{A_{m}\right\} /\left[E_{m}\right]$ is by definition the energy conductance (length-time ${ }^{-1}$ ). The latter concept is well-known from plant physiology (NOBEL, 1991). The rate at which energy is utilized from the storage, is

$$
\begin{aligned}
C & =-\left.\frac{d E}{d t}\right|_{f=0}=\left[E_{m}\right]\left(-\left.\frac{d e}{d t}\right|_{f=0} V-e \frac{d V}{d t}\right) \\
& =e\left[E_{m}\right]\left(V V^{2 / 3}-\frac{d V}{d t}\right)
\end{aligned}
$$

A fixed fraction $k$ of the utilized energy is spent on growth plus maintenance. The latter quantity is taken to be proportional to volume, $[M] V$.

So $\kappa C=[M] V+[G] \frac{d V}{d t}$,

where $[G]$ is the volume-specific costs for growth. Substitution gives:

$$
\frac{d V}{d t}=\frac{v^{2 / 3} e v-V g m}{e+g}
$$

where the dimensionless investment ratio, $g=[G] / \mathrm{k}\left[E_{m}\right]$, and the maintenance rate coefficient,
$m=[M] / G]$ are compound parameters. Growth ceases when the energy reserves drop below $e=V^{1 / 3} \mathrm{mg} / \mathrm{v}$. If the food density is constant long enough, (2) states that $e$ tends to $f$ and remains constant as well. This turns (4) into the well-known von Bertalanffy growth equation, having the solution

$$
V(t)=\left(V_{\infty}^{1 / 3}-\left(V_{\infty}^{1 / 3}-V_{0}^{1 / 3}\right) \exp \{-\gamma t\}\right)^{3}(\text { eq. 5) }
$$

where

$$
V_{\infty}^{1 / 3}=f \kappa\left\{A_{m}\right\} /[M]
$$

is the ultimate volume $e^{1 / 3}$ and

$$
\gamma=\left(3 / m+3 V_{\infty}^{1 / 3} / V\right)^{-1},
$$

the von Bertalanffy growth rate. The maximum volume $e^{1 / 3}$ is thus

$$
V_{m}^{1 / 3}=\kappa\left\{A_{m}\right\} /[M]=V / g m,
$$

which can only be reached at prolonged exposure to abundant food. The von Bertalanffy growth rate is then minimal and equals

$$
\frac{m}{3} \frac{g}{1+g}
$$

Back substitution of (4) into the storage utilization rate (3) gives

$$
C=\frac{e g\left[E_{m}\right]}{e+g}\left(v v^{2 / 3}+m V\right)
$$

In the absence of feeding and digestion, respiration is taken to be proportional to this utilization rate.

The maximum starvation time, i.e. the time until death by starvation, is found by setting the utilization rate in (2) equal to the maintenance rate for $f=0$. Neglecting the small size increase, for a well-fed individual, we arrive at a starvation time of

$$
\frac{V^{1 / 3}}{V} \ln \frac{V_{m}^{1 / 3}}{\kappa V^{1 / 3}}
$$

The energy drain to development plus reproduction equals $(1-k) C$. The maintenance of a certain degree of maturation is taken to be

$$
\frac{1-\kappa}{\kappa}[M] \min \left(V, V_{j}\right)
$$

This choice, which is an alternative way of defining $k$, makes the costs of development independent of the feeding conditions. The implication is that the cumulative energy drain to reproduction in adults, i.e. in individuals of a body volume larger than $V_{j}$, amounts to 


$$
\begin{aligned}
& R_{c}\left(t_{1}, t\right)= \\
& \int_{t_{1}}^{t} \frac{1-\kappa}{\kappa} \frac{e(s)}{e(s)+g}[G]\left(v V(s)^{2 / 3}+m V(s)\right) d s \\
& \quad-\frac{1-\kappa}{\kappa}[M]\left(t-t_{1}\right) V_{j}
\end{aligned}
$$

When growth ceases, the cumulated energy drain to reproduction in animals that continue to allocate energy to reproduction under these circumstances becomes

$$
\begin{aligned}
R_{C}\left(t_{1}, t\right)= & \left.\int_{t_{t}}^{t}\left(e(s)\left\{A_{m}\right\} V(s)^{2 / 3}-\mid M\right] V(s)\right) d s \\
& -\frac{1-\kappa}{\kappa}\left[M \mid\left(t-t_{1}\right) V_{j}\right.
\end{aligned}
$$

In animals like Mytilus, the energy feeding the drain to reproduction accumulates during the non-reproductive seasons inside the animal, but it is assumed not to be metabolically available for other purposes, see the section on reproduction. So, glycogen and lipid in the storage pool are different in their availability compared to glycogen and lipid in the reproductive pool. Reproduction is upon some internal or external stimulus. For the calculation of the actual reproduction, the cumulated energy has to be divided by the energy investment into a single sperm or egg. See KOOIJMAN (1986c) and ZONNEVELD \& KOOIJMAN (1993) for expressions of these costs on the assumptions that the initial embryo volume is negligibly small and that the energy density at hatching equals that of the mother at egg formation. At spawning, we assume a reset of $R_{c}$ to zero.

\section{SIZE}

Frequently used measures of size of mussels are shell length, wet weight, dry weight and ash-free dry weight. For animals like mussels, wet weight, $W_{w}$, relates in a simple way to body volume, assuming a constant specific density close to $d_{w}=1 \mathrm{~g} \cdot \mathrm{cm}^{-3}$. The rationale is that storage compounds replace water (PIEITERS et al., 1979) and have about the same specific density. For isomorphs, shell length relates to volume as $d_{m} L=V^{i / 3}$, where $d_{m}$ is called the shape coefficient. Fig. 1 confirms this relation. The data represented imply that the shape coefficient $d_{m}=0.333$ (SD 0.097). KOOIJMAN (1988) estimated a shape coefficient of 0.394 based on the intra-shell volume.

The advantage of length above wet weight is that it allows an easy and accurate measurement which is not destructive. Dry weight or ash-free dry weight of the soft parts is a weighted sum of volume, $V$, storage materials, $E$, and cumulated reproductive material, $R_{c}$. The compounds $E$ and $R_{c}$ vary with habitat and season (PIETERS et al., 1979; ZANDEE et al., 1980). Dry weights of the soft parts of a $4.0 \mathrm{~cm} \mathrm{M}$. edulis take values as extreme as $130 \mathrm{mg}$ and $630 \mathrm{mg}$, and beyond (JØRGENSEN, 1976).

The largest mussels found in nature tend to occur in subarctic and arctic regions because of the high food densities (REMMERT, 1980). THEISEN (1973) and THOMPSON (1984) report mean shell lengths of 9.2 and $9.4 \mathrm{~cm}$ in Greenland and Newfoundland, respectively. Theisen reports shell lengths exceeding 9.2 $\mathrm{cm}$. Unfortunately, he gave no actual lengths because these shells were lost. The theoretical maximum will certainly be higher, because plankton densities fall in winter.

\section{TEMPERATURE}

Acute and long-term responses of $M$. edulis to temperature changes have been described by several authors; for a review see BAYNE (1976) and JØRGENSEN (1990). Knowledge of long term-temperature responses is needed for comparing experiments carried out under different temperature regimes. The long-term temperature response is also needed for applying the model to field conditions with seasonally fluctuating temperatures.

The way rates depend on temperature is usually well described by the Arrhenius relation within a spe-

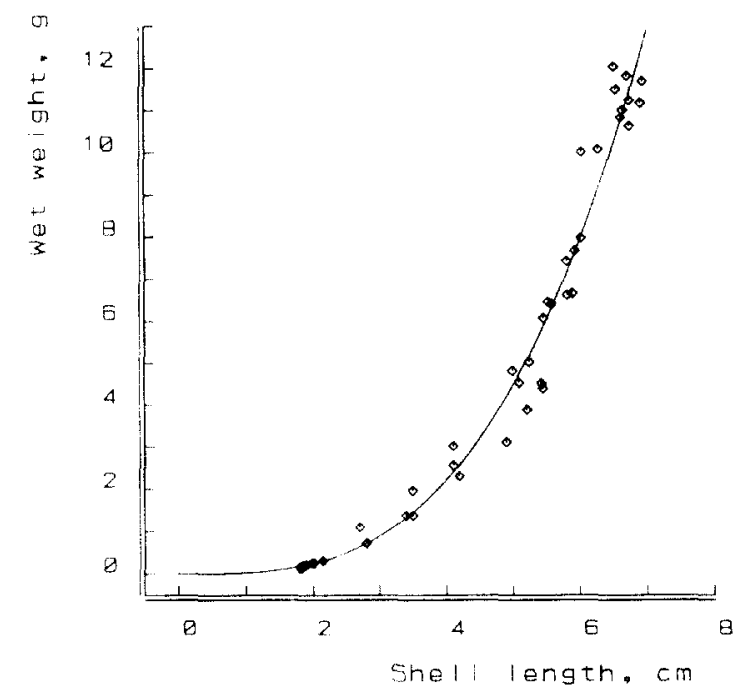

Fig. 1. The relation between shell length, $L$ and fresh (wet) weight, $W_{w}$. Data from BORCHARDT (1985); PIETERS et al. (1979); Dutch contribution to ICES, Copenhagen. The leastsquares fitted curve is $W_{w}=d_{w}\left(d_{m} L\right)^{3}$ with $d_{w}=1 \mathrm{~g} \cdot \mathrm{cm}^{-3}, d_{m}{ }^{3}$ $=0.03692$ (SD 7.59.10.5). It does not differ significantly from the best-fitting allometric one $W_{w}=0.02774 L^{3.157}$ on the basis of the likelihood ratio test $(p=0.096)$. 
cies-specific tolerance range (KOOIJMAN, 1988). In $M$. edulis the range is 5 to $20^{\circ} \mathrm{C}$ (WIDDOWS \& BAYNE, 1971; WIDDOWS, 1973). At lower temperatures, the actual rates are lower than expected because the animal remains in a kind of resting phase until the temperature rises again (KOOIJMAN, 1988). At higher temperatures, animals usually die. Lethal temperatures for sublittoral $M$. edulis vary from $27^{\circ} \mathrm{C}$ to $40^{\circ} \mathrm{C}$ as a function of the exposure regime (BAYNE, 1976).

The Arrhenius temperature is estimated using growth rates of larval shell length (Fig. 2). We assume that, as a first approximation, all physiological rates are affected in the same way with deviations at temperatures exceeding $20^{\circ} \mathrm{C}$. NIELSEN (1988) and WIDDOWS \& BAYNE (1971) report decreasing growth rates of (juvenile) mussels with increasing temperatures, which is in contrast with the expected increasing growth rates (Fig. 2). The explanation might be in the depletion of food at higher temperatures due to elevated metabolic rates.

Results of WIDDOWS (1978) and WIDDOWS et al. (1979) suggest that there is no long-term effect of temperature on filtration rates of $M$. edulis when rates are corrected to a standard weight of $1 \mathrm{~g}$ dry weight. However, during the season, food tends to co-vary with temperature; so do the reserves and thus the dry weights. Standardization on the basis of dry weights therefore obscures the effect of temperature, if the change rate in reserves matches with that of temperature. We use an Arrhenius temperature correction for filtering rates as well, the Arrhenius temperature being $T_{A}=7600 \mathrm{~K}$. The rate at absolute temperature $T_{1}$ is thus obtained from that at $T_{0}$ according to

$$
v_{T_{1}}=v_{T_{0}} \exp \left\{T_{A}\left(1 / T_{0}-1 / T_{1}\right)\right\} \text {. }
$$

\section{FOOD}

Since energy uptake depends on food availability and quality, some remarks on food for mussels are in order.

Suspended particles in natural conditions are mixtures of organic and inorganic compounds which vary in size. If larger than $\mathbf{4} \mu \mathrm{m}$ in diameter, they are fully retained by $M$. edulis whereas a $50 \%$ retention is reported for particles of $1 \mu \mathrm{m}$ in diameter (VAHL, 1972; MOHLENBERG \& RIISGÄRD, 1978). Particles less than 1 $\mu \mathrm{m}$ are poorly utilized (WRIGHT et al., 1982; GORHAM, 1988). Field monitoring programmes frequently use the $0.45 \mu \mathrm{m}$ mesh sieve to distinguish 'dissolved' from particulate or suspended matter (SM). This criterion is also used in the following sections. Thus $M$. edulis will be able to retain most of the particulate matter suspended in the water column.

Particulate organic matter (POM, defined as SM minus its ash weight) is the major food component for $M$. edulis. LAANE et al. (1987) distinguish a refractory fraction which cannot be utilized by metazoans. The non-refractory fraction of POM mainly consists of

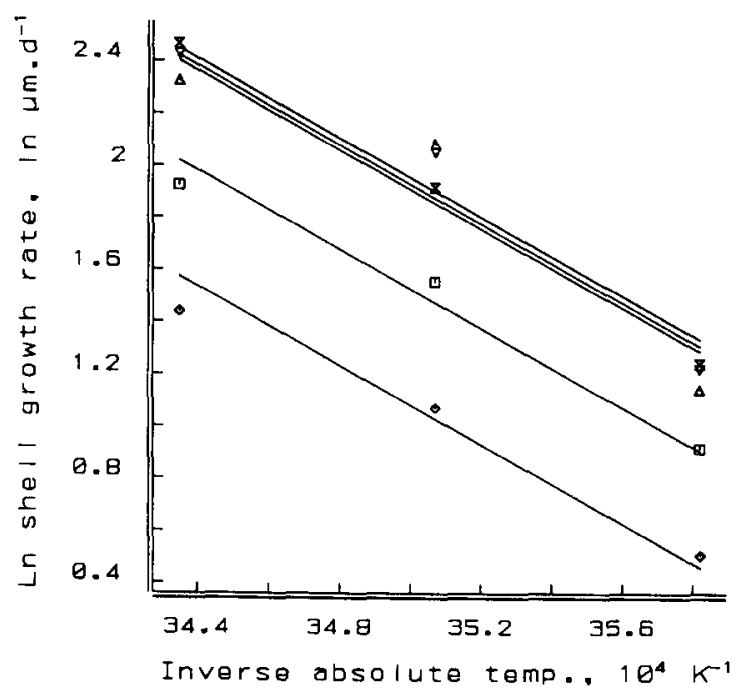

Fig. 2. Arrhenius plot for shell-length growth rates of larval mussels at $2,5,10,20$ and 40 cells isochrysis $\mathrm{mm}^{-3}$. Data from SPRUNG (1984). The Arrhenius temperature is 7579 (SD 167) K.

phytoplankton and detritus. POM in estuaries originates from autochthonous production and allochthonous sources (rivers and coastal waters). The detritus concentration in estuaries and coastal waters far exceeds the concentration of phytoplankton (LAANE et al., 1987). RODHOUSE et al. (1984) explained high length growth rates of $M$. edulis in winter by allochthonous detritus input to the estuary.

The nutritive value of POM can be estimated by the protein, carbohydrate and lipid contents (WIDDOWS et al., 1979; LAANE et al., 1987). The nutritive value expressed as energy per mg SM varies considerably among estuaries and seasons. Typical yearly ranges are 22.2-24.8 J.mg SM-1 (Lynher estuary, U.K., WIDDOWS et al., 1979), 0.29-15.9 J.mg SM-1 (Gironde, France, LAANE et al., 1987), 0.18-5.9 J.mg SM${ }^{-1}$ (Ems-Dollard estuary, the Netherlands, LAANE et al., 1987). The nutritive fraction of SM follows a seasonal cycle, similar to that recorded for percentage ash-free material of SM (WIDDOWS et al., 1979). The POM concentration in water can be used as a measure of food energy for $M$. edulis after conversion of POM to its mean energy equivalent of $20.3 \mathrm{~J} \cdot \mathrm{mg} \mathrm{POM}^{-1}$ (BAYNE et al., 1987).

\section{FEEDING, INGESTION AND ASSIMILATION}

High SM concentrations ( 2.6 to $5 \mathrm{mg} \cdot \mathrm{dm}^{-3}$, WIDDOWS et al., 1979; 3.2 to $7.4 \mathrm{mg} \cdot \mathrm{dm}^{-3}$, BAYNE et al., 1989) induce the production of pseudofaeces, consisting of material cleared from suspension but rejected by the mussel before ingestion. Selection for the digestible fraction of SM is demonstrated by KIØRBOE et al. 


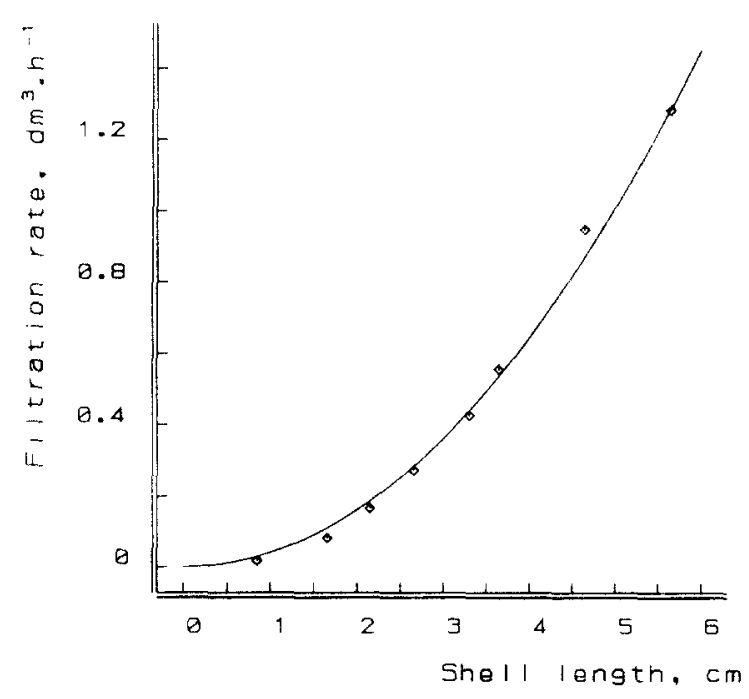

Fig. 3. Filtration rate as function of shell length, $L$, at constant food density $\left(40 \cdot 10^{6}\right.$ cells. $\mathrm{dm}^{-3}$ Dunaliella marina) at $12^{\circ} \mathrm{C}$. Data from WINTER (1973). The least-squares fitted curve is $\{F\}\left(d_{m} L\right)^{2}$, with $\{F\}=0.041$ (SD $6.75 \quad 10^{4}$ ) $\mathrm{dm}^{3} \cdot \mathrm{h}^{-1} \cdot \mathrm{cm}^{-2}$, which does not differ significantly from the best-fitting allometric one $0.039 L^{2.03}$ on the basis of the likelihood ratio test $(p=0.66)$.

(1980), who used mixtures of resuspended sediments with cultured algae in their experiments. However, FOSTER-SMITH (1975b) and WIDDOWS et al. (1979) found no selection. The labial palp plays a role in sorting incoming material, which is conveyed to the mouth or to the rejection tracts (BAYNE, 1976). THEISEN (1982) has shown that palp size increases with increasing SM concentrations in water. He suggests that large palp size is an adaption to life in turbid waters.

Food intake is a function of body size, particle concentration, and pseudofaeces production (WINTER, 1978). A retention efficiency of $100 \%$ for POM is assumed here. This is realistic under most field conditions. We also assume that the fraction of POM in pseudofaeces is negligible. Filtration and ingestion rates are closely related for food densities low enough to prevent pseudofaeces production. At such densities, all the filtered material is ingested.

FOSTER-SMITH (1975a) found that the square root of the gill area is proportional to shell length. Fig. 3 shows that filtering rate is proportional to squared length. Since no pseudofaeces occurred, ingestion is likely to be proportional to squared length as well. WINTER (1978) and MOHLENBERG \& RIISGARD (1979) reported scaling parameters for wet weights of 0.73 at constant food density of $40 \cdot 10^{6}$ cells. dm ${ }^{-3}$ and 0.66 at different food densities. In WINTER's review (1978) scaling parameters are reported to vary between 0.27 and 0.82 for dry weights.

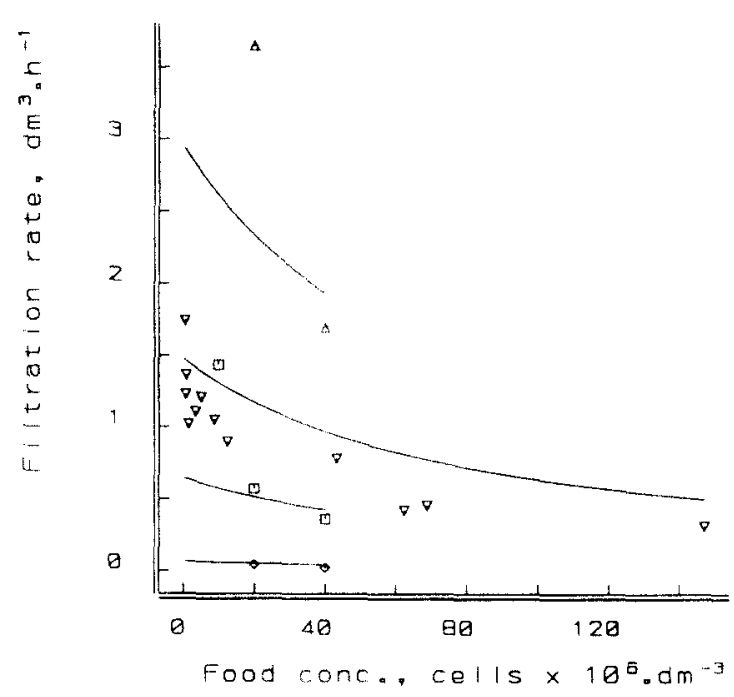

Fig. 4. Filtration rate, $F$, as function of food concentration, $X$, for different shell lengths, $L$. Rates are corrected to $15^{\circ} \mathrm{C}$ and shell lengths are (from bottom to top) resp. $0.85,2.65,4$ and $5.65 \mathrm{~cm}$. Data from WINTER (1973) and SCHULTE (1975) (4 $\mathrm{cm}$ only). The simultaneously least-squares fitted curves are $F=\left\{F_{m}\right\}\left(d_{m} L\right)^{2} /(1+X / K)$ with $\left\{F_{m}\right\}=0.83$ (SD 0.098) $\mathrm{dm}^{3} \cdot \mathrm{cm}^{-2} \cdot h^{-1}$ and $K=76$ (SD 42) $10^{6}$ cells $\cdot \mathrm{dm}^{-3}$.

At high food densities, the food handling organs (cirri, gill filaments, mucus strings, labial palp and gut) become saturated. FOSTER-SMITH (1975b), RIISGARD \& MØHLENBERG (1979) and RIISGARD \& RANDLOV (1981) observed decreasing filtration rates at increasing food densities. This decrease has obviously the function of providing the ingestive system with limited amounts of food it can handle. Fig. 4 shows the fitted filtration rates at four different shell lengths as a function of food density. The rates are corrected to $15^{\circ} \mathrm{C}$.

In very dilute suspensions $M$. edulis ceases filtering (BAYNE, 1976). RIISGARD \& RANDLøV (1981) reported a threshold food concentration of $1.5 \cdot 10^{6}$ Phaeodactylum tricornutum cells. $\mathrm{dm}^{-3}$ for a $2 \mathrm{~cm}$ mussel (approximately $0.024 \mathrm{mg}$ dry weight. $\mathrm{dm}^{-3}$, KIØRBOE et al., 1981), below which no filtration occurs due to shell closure. After a 24-day period at a constant low or high food level, $M$. edulis reacts within an hour to changes in algal concentrations by opening or closing its shell.

Fig. 5 shows the ingestion rate as function of food density at different shell lengths. The maximum ingestion rate coincides with the threshold concentration at which pseudofaeces production starts. BAYNE et al. (1989) reported a maximum ingestion rate for a $2.5 \mathrm{~cm}$ mussel of $1.8 \mathrm{mg} \mathrm{POM} \cdot \mathrm{h}^{-1}$ (corresponds in his experiments with an SM concentration of 7.43 $\mathrm{mg} \cdot \mathrm{dm}^{-3}, 14^{\circ} \mathrm{C}$ ) which is close to the calculated value of $1.64 \mathrm{mg}$ POM $\cdot \mathrm{h}^{-1}$ based on the fitted curves in Fig. 5. So the assumption of $100 \%$ sorting efficiency is 
$\mathbf{x}$

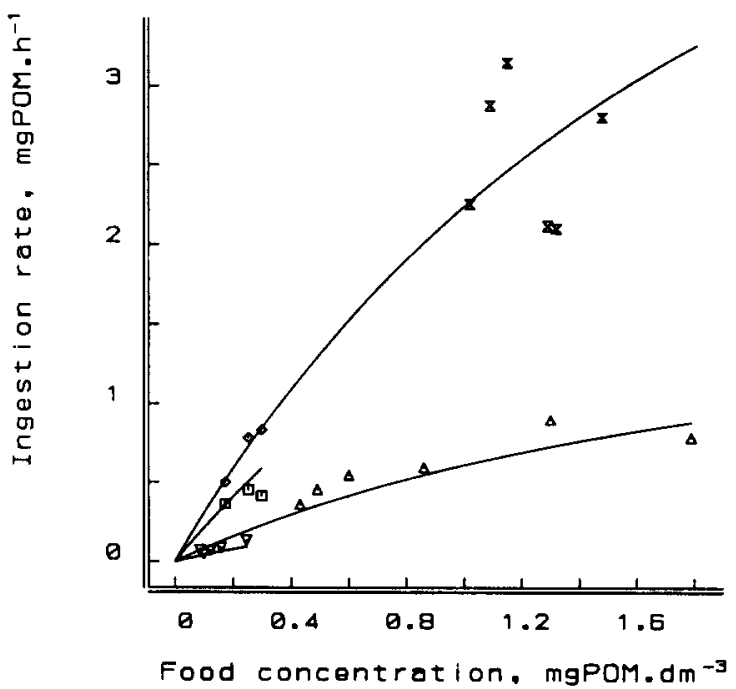

Fig. 5. Ingestion rate, $I$, as function of food concentration, $X$, for different shell lengths, $L$. Food is added as mixtures of algae or organic matter with silt (inorganic particles). Rates are corrected to $15^{\circ} \mathrm{C}$ and the shell lengths are resp. (from bottom to top) $1.75,2.5,4.25$ and $4.8 \mathrm{~cm}$. Data from resp. KIøRBOE et al. (1981); BAYNE ot al. (1989); BAYNE et al. (1987) and Smaal (pers. comm.). The simultaneously leastsquares fitted curves are $\left.L_{-1}\right\}\left(I_{m} L\right)^{2} X(K+X)$, with $\left\{I_{m}\right\}=3.0$ (SD 1.0) $\mathrm{mg} P O M \cdot \mathrm{cm}^{-2} \cdot \mathrm{h}^{-1}$ and $K=2.4$ (SD 1.3) $\mathrm{mg}$ POM.dm.

corroborated by these results. Fig. 6 confirms that the gut passage time is inversely related to ingestion rate, which implies that the food loading of the digestive system remains constant.

The assimilation efficiency of food in the gut depends on food density (BAYNE, 1976) or ingestion rate (FOSTER-SMITH, 1975b; BORCHARDT, 1985). When data from several sources are combined, these dependencies are not obvious, see Fig. 7 . The presented assimilation rates were obtained by multiplication of the assimilation efficiency of CONOVER (1966) by the ingestion rate and the 'mean' energy equivalent of POM. This leads to an average food-energy conversion of $\left\{A_{m}\right\} /\left\{I_{m}\right\}=11.5 \mathrm{~J} \cdot \mathrm{mg}^{-1} \mathrm{POM}$, which is 0.57 times the 'mean' energy equivalent of POM.

\section{RESPIRATION AND MAINTENANCE}

The oxygen consumption rate as function of length at constant food densities is shown in Fig. 8. On the basis of the DEB model, we expect a proportionality of the oxygen consumption rate to $V+V^{2 / 3} v / m$, which closely resembles the frequently postulated one to $W^{0.75}$ based on weight (KOOIJMAN, 1986a; EVERS \& KOOIJMAN, 1989). The scaling parameter for $M$. edulis varies between 0.595 and 0.930 at different tempera-

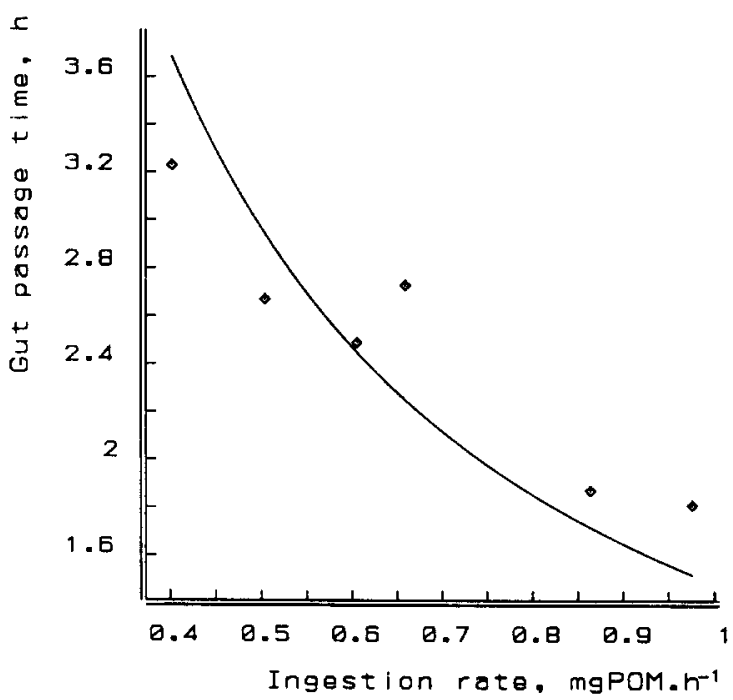

Fig. 6. Gut-passage time as a function of ingestion rate for a $2.5-\mathrm{cm}$ mussel feeding on a mixture of Isochrysis galbana, Phaeodactylum tricornutum and ashed silt at $14^{\circ} \mathrm{C}$. Data from BAYNE et al. (1989). The least-squares fitted curve is $T$ $=V_{g} / l$, with gut content $V_{g}=1.48$ (SD 0.077) mg POM.

tures and dry weights (BAYNE, 1976). HAMBURGER et al. (1983) found a scaling parameter of 0.903 for veliger larvae and 0.663 for adult mussels. They based their calculations on dry weight instead of wet weight or shell length, which biases the estimation of the scaling parameters by the fact that energy reserves do contribute substantially to dry weights, while not requiring energy for maintenance.

Three different levels of oxygen consumption rate of $M$. edulis have been empirically identified by THOMPSON \& BAYNE (1972) in relation to changes in food density. The standard oxygen consumption rate is defined in the absence of food when the oxygen consumption rate declines to a steady state. The active oxygen consumption rate is reached when a starved mussel is fed. Between the limits of standard and active oxygen consumption rates the mussel can show several routine oxygen consumption rates (BAYNE, 1976). THOMPSON \& BAYNE (1974) showed that the oxygen consumption rate depends hyperbolically on the ingestion rate. This is consistent with the DEB model, if the contribution of filtration, ingestion and digestion to respiration is negligible (WIDDOWS \& HAWKINS, 1989, JØRGENSEN, 1990). Substitution of equation (1) into (6) leads to

$$
O_{r}=O_{s} \frac{I}{V} \frac{V^{1 / 3}+v / m}{I V^{2 / 3}+g\left\{I_{m}\right\}}
$$




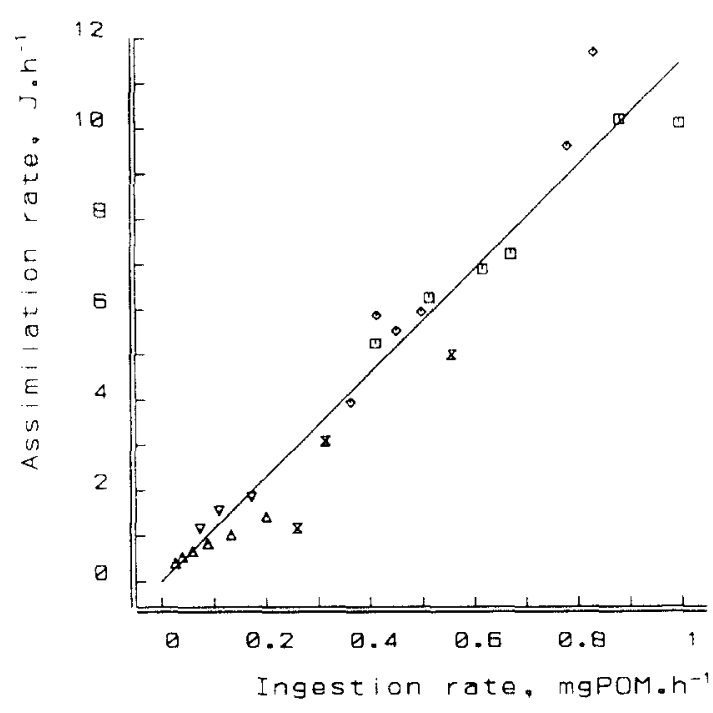

Fig. 7. Assimilation rate as a function of ingestion rate for mussels ranging from 1.75 to $5.7 \mathrm{~cm}$. Data from BAYNE et al. (1987); BAYNE et al. (1989); BORCHARDT (1985); KIØRBOE et al. (1981) and HAWKINS \& BAYNE (1984). All rates are corrected to $15^{\circ} \mathrm{C}$. The fitted line is $A=I\left\{A_{m}\right\} /\left\{I_{m}\right\}$ with $\left\{A_{m}\right\} /\left\{I_{m}\right\}=$ 11.5 (SD 0.34) J.mg POM ${ }^{-1}$.

where the proportionality constant $\mathrm{O}_{s}\left(\mathrm{~cm}^{3} \mathrm{O}_{2} \cdot \mathrm{h}^{-1}\right)$ stands for the standard oxygen consumption rate of an individual. This is so because a prolonged ingestion rate of $\left\{I_{m}\right\} V V_{m}^{-1 / 3}$ just balances the maintenance costs $V M / \kappa$. At maximally prolonged ingestion, when $I=\left\{I_{m}\right\} V^{R / 3}$, the oxygen consumption rate thus becomes

$$
O_{r}=O_{s} \frac{1+V^{-1 / 3} v / m}{1+g}
$$

This corresponds with the active oxygen consumption rate of THOMPSON \& BAYNE (1972). In Fig. 9 the oxygen consumption is related to ingestion for mussels of different sizes. The estimated parameters are not very useful because a slight deviation in the shell lengths causes a large deviation in the parameter estimates.

After the cessation of growth, oxygen consumption, $O_{r}$, during starvation is proportional to the energy spent on maintenance plus reproduction. It decreases exponentially at a rate proportional to body length (KOOIJMAN, 1986b; EVERS \& KOOIJMAN, 1989) in animals that do not change their storage dynamics and continue to allocate energy to reproduction

$$
O_{N}(t)=\left\{O_{0}\right\} V^{2 / 3} \exp \left\{-v t V^{1 / 3}\right\}
$$

where $\left\{O_{0}\right\}$ is the proportionality constant $\left(\mathrm{cm}^{3}\right.$ $\mathrm{O}_{2} \cdot \mathrm{cm}^{-2} \cdot \mathrm{h}^{-1}$ ) which depends on the food history at the start of the experiment. Fig. 10 shows oxygen consumption rate and carbohydrate weight as functions

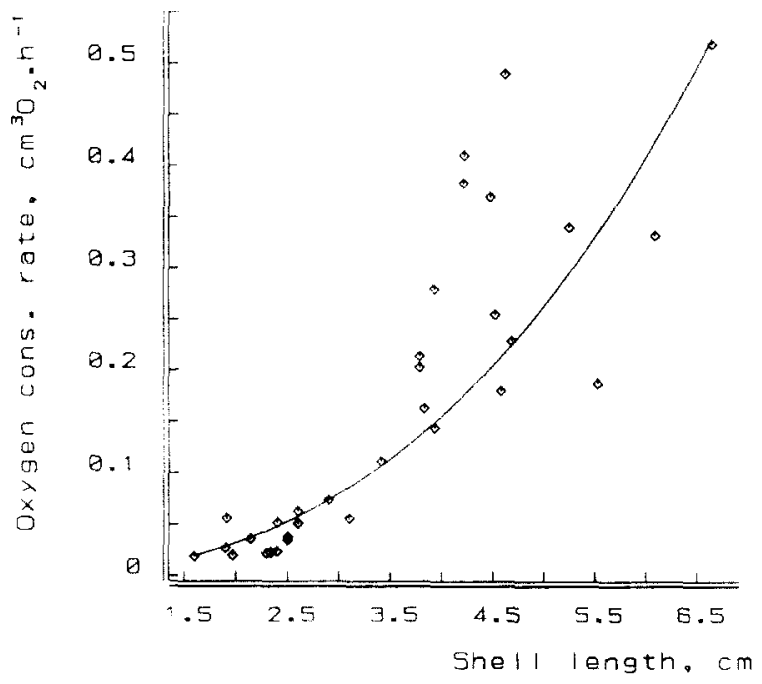

Fig. 8. Oxygen consumption rate as function of shell length, $L$, at constant food density at $15^{\circ} \mathrm{C}$. Data from KRUGER (1960). The least-squares fitted curve is $O_{r}=\left[O_{0}\right]\left(L^{3}+v / m^{2}\right)$ with $\left[O_{0}\right]=0.022\left(\right.$ SD 0.0074) $\mathrm{cm}^{3} \mathrm{O}_{2} \cdot \mathrm{cm}^{-3} \cdot \mathrm{h}^{-1}$ and $\mathrm{v} / \mathrm{m}=$ 26.5 (SD 14.8) $\mathrm{mm}$.

of starvation time at two different body sizes. Respiration rate and dry weight decrease in parallel during starvation. Standardization of respiration rate on dry weight of the mussel obscures the effect of stanvation on respiration and results in a 'constant' respiration

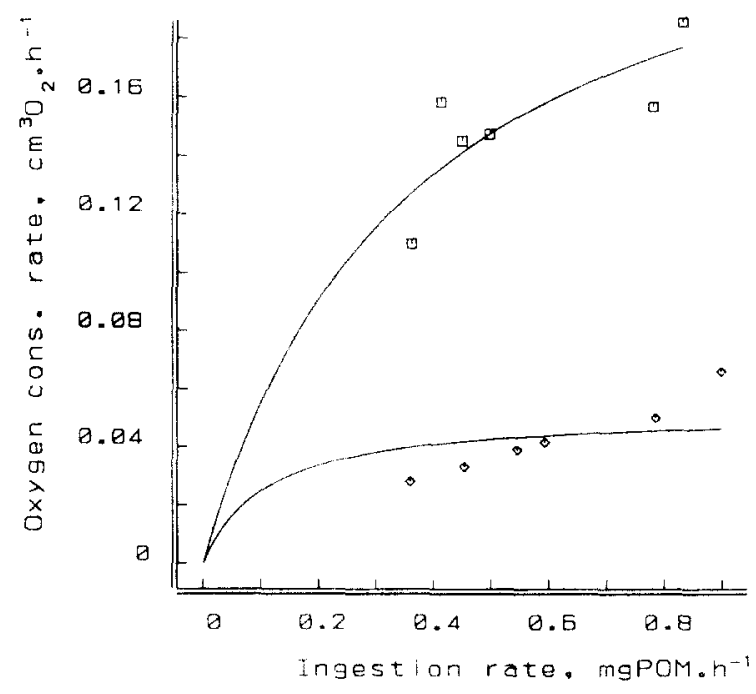

Fig. 9. Oxygen consumption rate as function of ingestion rate, $I$, for the shell lengths of 2.5 and $4.5 \mathrm{~cm}$. Data from BAYNE et al. $(1987,1989)$. Rates are corrected to $15^{\circ} \mathrm{C}$. The simultaneously least-squares fitted curves are $O_{r}=\left(O_{s} l / d_{m} L\right)\left(\left\{d_{m} L+v / m\right] /\left[/\left(d_{m} L\right)^{-2}+g\left\{I_{m}\right\} \mid\right) \quad\right.$ with $O_{s}\left(d_{m} L\right)^{-3}=0.056(\mathrm{SD} 0.025) \mathrm{cm}^{3} \mathrm{O}_{2} \cdot \mathrm{h}^{-1} \cdot \mathrm{cm}^{-3}, v / m=5.3$ (SD 6.5) $\mathrm{mm}, g\left\{I_{m}\right\}=0.16(\mathrm{SD} 0.07) \mathrm{mg} \mathrm{POM} \cdot \mathrm{cm}^{-2} \cdot \mathrm{h}^{-1}$. 


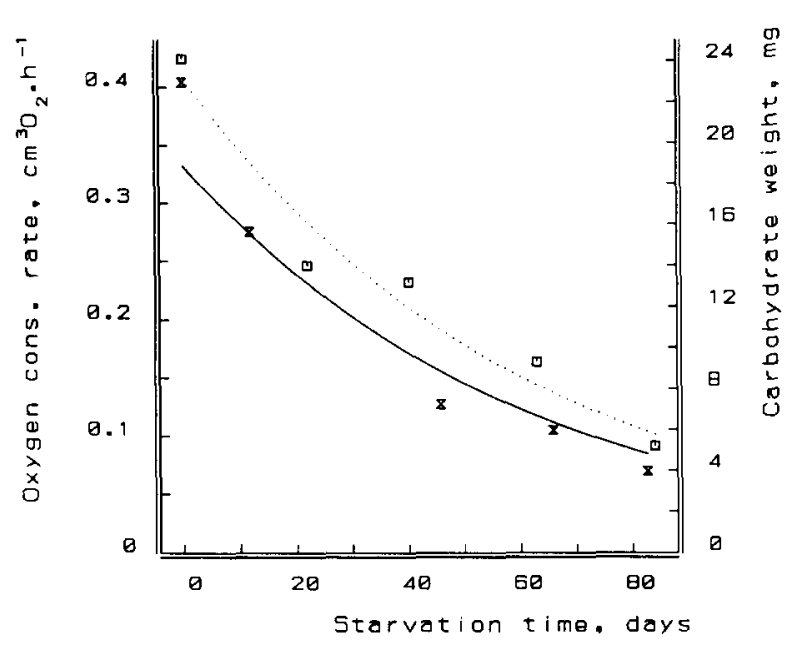

Fig. 10. Oxygen consumption rates, $(x)$, and the carbohydrate weights (D), in starving $4.5 \mathrm{~cm}$ mussels at $15^{\circ} \mathrm{C}$. Data from BAYNE \& THOMPSON (1970). The simultaneous leastsquares fitted curves are $O(t)=O_{0} \exp \left\{-v t / d_{m} L\right\}$, with $O_{0}=$ 0.33 (SD 0.046) $\mathrm{cm}^{3} \mathrm{O}_{2} \cdot \mathrm{h}^{-1}$ and $v=0.25$ (SD 0.009) $\mathrm{mm} \cdot \mathrm{d}^{-1}$ and $V(t)=W_{0} \exp \left\{-v t / d_{m} L\right\}$, with $V_{0}=23.2($ SD 0.55) $\mathrm{mg}$.

rate. The estimated value of the energy conductance $v$ at $15^{\circ} \mathrm{C}, 0.25$ (SD 0.009$) \mathrm{mm} \cdot \mathrm{d}^{-1}$ is close to the value of 0.22 (SD 0.018$) \mathrm{mm} \cdot \mathrm{d}^{-1}$ estimated with data of decreasing lipid weights during starvation (ADEMA, 1981).

\section{GROWTH}

Age is usually determined in the field on the basis of rings in the shell (LUTZ, 1976; RICHARDSON, 1989), size frequencies (e.g. BAYNE \& WORRALL, 1980), or it is known in experimental setups (e.g. KAUTSKY, 1982b). When food density is constant or when food

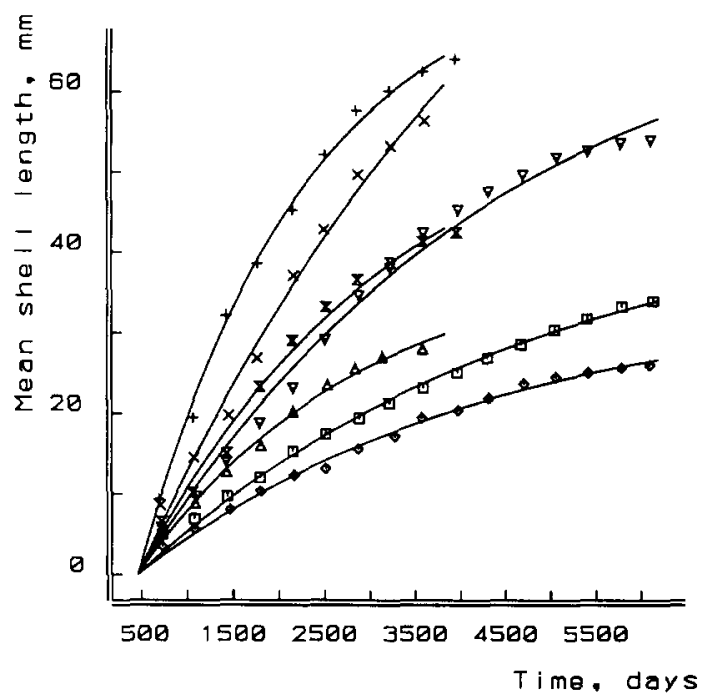

Fig. 11. Von Bertalanffy growth curves fitted to length-time data, as reported by SEED (1969b) on intertidal North Sea mussels. The parameter values are listed in Table 2.

is abundant, the von Bertalanffy growth curve (5) should fit. The fit is mostly satisfying (see Fig. 11 and Table 2). This implies that the yearly means of food density and temperature remain more or less constant at the sites of sampling (exposed rocky shores in Yorkshire, U.K., SEED, 1969b).

Sigmoid growth curves, like the age-based Gompertz growth curve, sometimes fit available data better (THEISEN, 1973; BAYNE \& WORRALL, 1980). Variations in food density and/or temperature affect growth in such a way that the solution of equations (2) and (4) can take almost any shape (KOOIJMAN, 1988). KAUTSKY (1982b) measured the mussels indi-

TABLE 2

Ultimate shell lengths $\left(L_{\infty}\right)$ and von Bertalanffy growth rates $(\gamma)$, (with SD). $\ddagger$ estimated mean temperature at site of sampling. * a: size frequency; $b$ : measured age; $c$ : shell rings.

\begin{tabular}{lcccc}
\hline \multicolumn{1}{c}{ source } & $\begin{array}{c}\text { sample } \\
\text { method }^{*}\end{array}$ & temp. ${ }^{\circ} \mathrm{C}$ & $L_{\infty}(\mathrm{cm})$ & $\gamma\left(d^{-5}\right)$ \\
\hline RODHOUSE et al. (1984) & $\mathrm{c}$ & 11 & $9.60(0.157)$ & $2.9510^{-4}\left(1.1310^{-5}\right)$ \\
& $\mathrm{c}$ & 11 & $7.46(0.296)$ & $3.4510^{-4}\left(2.5310^{-5}\right)$ \\
PAGE \& HUBBARD (1987) & $\mathrm{c}$ & 11 & $6.01(0.429)$ & $3.3910^{-4}\left(4.3810^{-5}\right)$ \\
BAYNE \& WORRALL (1980) & $\mathrm{b}$ & 14.8 & $9.07(0.043)$ & $5.2610^{-3}\left(5.4510^{-5}\right)$ \\
SEED (1969b) & $\mathrm{a}$ & $10 \pm$ & $10.8(2.61)$ & $3.7410^{-4}\left(1.3010^{-4}\right)$ \\
& $\mathrm{c}$ & & $3.46(0.282)$ & $2.5610^{-4}\left(3.6110^{-5}\right)$ \\
& $\mathrm{c}$ & & $4.70(0.360)$ & $2.2410^{-4}\left(2.8010^{-5}\right)$ \\
& $\mathrm{c}$ & & $3.97(0.461)$ & $4.1410^{-4}\left(7.9610^{-5}\right)$ \\
& $\mathrm{c}$ & & $7.48(0.313)$ & $2.4810^{-4}\left(1.8110^{-5}\right)$ \\
& $\mathrm{c}$ & & $6.19(0.485)$ & $3.5210^{-4}\left(4.5610^{-5}\right)$ \\
& $\mathrm{c}$ & & $12.2(1.74)$ & $2.0510^{-4}\left(3.8910^{-5}\right)$ \\
\hline
\end{tabular}




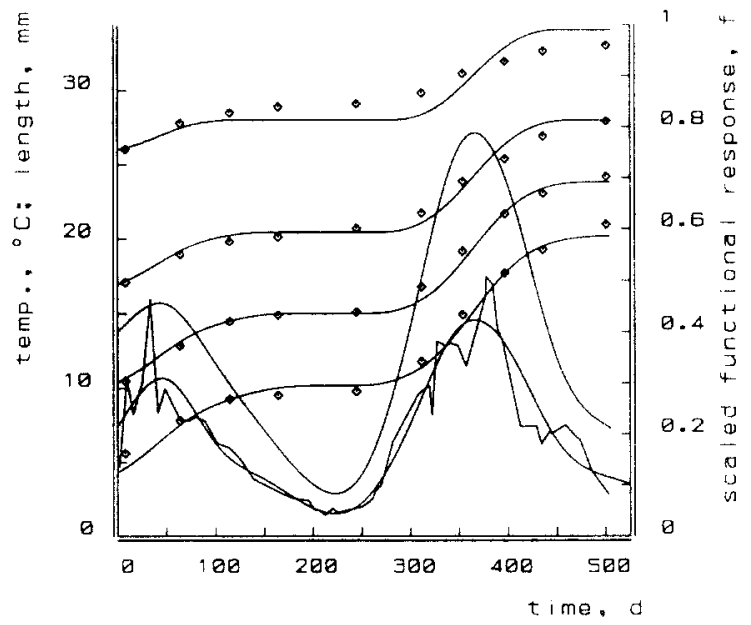

Fig. 12. Reconstruction of scaled functional response since 1 August from mean length-time data as reported by KAUT. SKY (1982b), given a cubic spline description of the measured temperature. Initial lengths were 4.3, 10.4, 17 and 26 mm. Parameters: $L_{m}=100 \mathrm{~mm}, g=0.13, m_{15}=0.03 d^{-1}, T_{A}=$ $7600 \mathrm{~K}$.

vidually in cages $(\varnothing 10 \mathrm{~cm}$ ) at a depth of $15 \mathrm{~m}$ in the Baltic at a salinity of $S=7$. These data, see Fig. 12, clearly show the annual cycle in growth. Assuming that the rates depend on temperature in an Arrhenius way and that the change in food density is slow enough to approximate the energy reserves with $e=f$, equation (4) can be used to reconstruct the (not measured) food density. So, the predicted length is found from

$$
\begin{aligned}
\frac{d}{d t} L= & \frac{\left(L_{m} f(t)-L\right)}{3(f(t)+g)}+g m_{15}\left(T(t)>T_{0}\right) \\
& \quad \exp \left\{T_{A}\left(\frac{1}{288}-\frac{1}{T(t)}\right)\right\}
\end{aligned}
$$

where $m_{15}$ denotes $m$ at $15^{\circ} \mathrm{C}$. We used a cubic spline function to describe temperature $T(t)$. The reconstruction of scaled food density $f(t)$ from the length-time data then amounts to the estimation of the values at chosen time points. In view of the scatter, which increases in time in the upper size class in the original data, the fit is acceptable. This illustrates that there is no need to modify equation (4) to describe sigmoid growth curves. The von Bertalanffy growth rate at $f=1$ is $0.42 y^{-1}$ at $15^{\circ} \mathrm{C}$ on the basis of the parameter values given in Fig. 12. The ratio of the peaks of the scaled functional responses is 1.66 . The peak temperatures differ $4^{\circ} \mathrm{C}$, which corresponds with a factor of 1.45 in the maximum surface-specific uptake rates of mussels as well as algae. The remaining difference in primary production could pos-

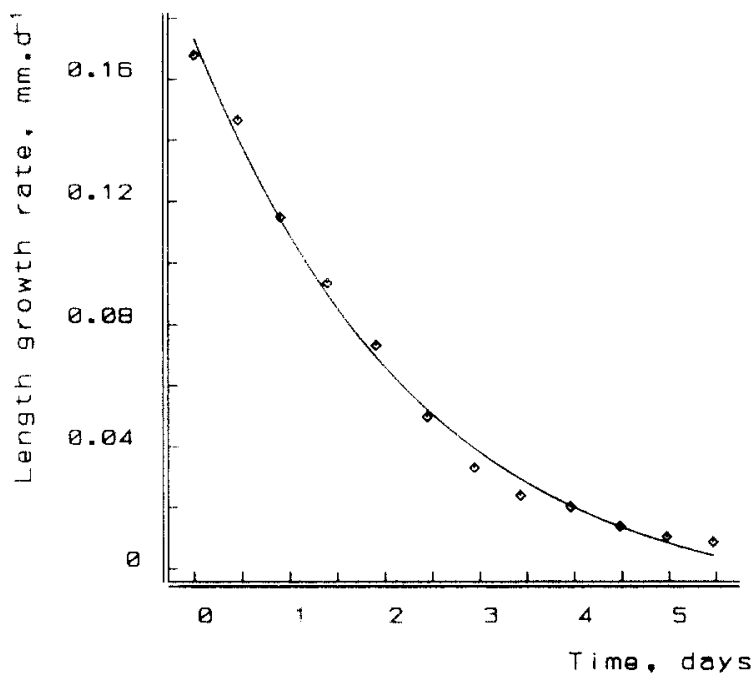

Fig. 13. Growth rates in starved mussels at $21.8^{\circ} \mathrm{C}$. Data from STROMGREN \& CARY (1984). The fitted curve is $d L d t=$

$\left(v \exp \left\{-v t / d_{m} L\right\}-m d_{m} L g / e_{0}\right) /\left(3 d_{m}\left(\exp \left\{-v t / d_{m} L\right\}+g / e_{0}\right)\right)$

with the shape coefficient $d_{m}=0.333$ and $L=1.7 \mathrm{~cm}$. The least-squares estimates were $g / e_{0}=12.59$ (SD 1.21) $m=$ 2.36 (SD 0.99 ) $10^{-3} \mathrm{~d}^{-1}$ and $v=2.52$ (SD 0.183 ) mm.d

sibly be explained by an increase in received solar radiation with temperature.

STRÖMGREN \& CARY (1984) found growth rates of shell length to decrease during starvation. This can be described by equations (2) and (4). During the experiment, the mussels in the range of $12-22 \mathrm{~mm}$ grew $0.75 \mathrm{~mm}$. When we neglect the change in length, equation (2) gives

$$
e(t)=e_{0} \exp \left\{-\frac{v t}{d_{m} L}\right\}
$$

Substitution into (4) gives

$$
\frac{d L}{d t}=\frac{v \exp \left\{-\frac{v t}{d_{m} L}\right\}-d_{m} L m \frac{g}{e_{0}}}{3 d_{m}\left(\exp \left\{-\frac{v t}{d_{m} L}\right\}+\frac{g}{e_{0}}\right)}
$$

Fig. 13 shows a good fit. The parameter values lose a bit of their value by the broad length range of the mussels and the way they are selected for measurement.

We finally consider growth in situations where temperatures and food availabilities changed and have been measured; see Fig. 14. The estimation of food density during the season from field data is difficult, and therefore a smoothed cubic spline function is 

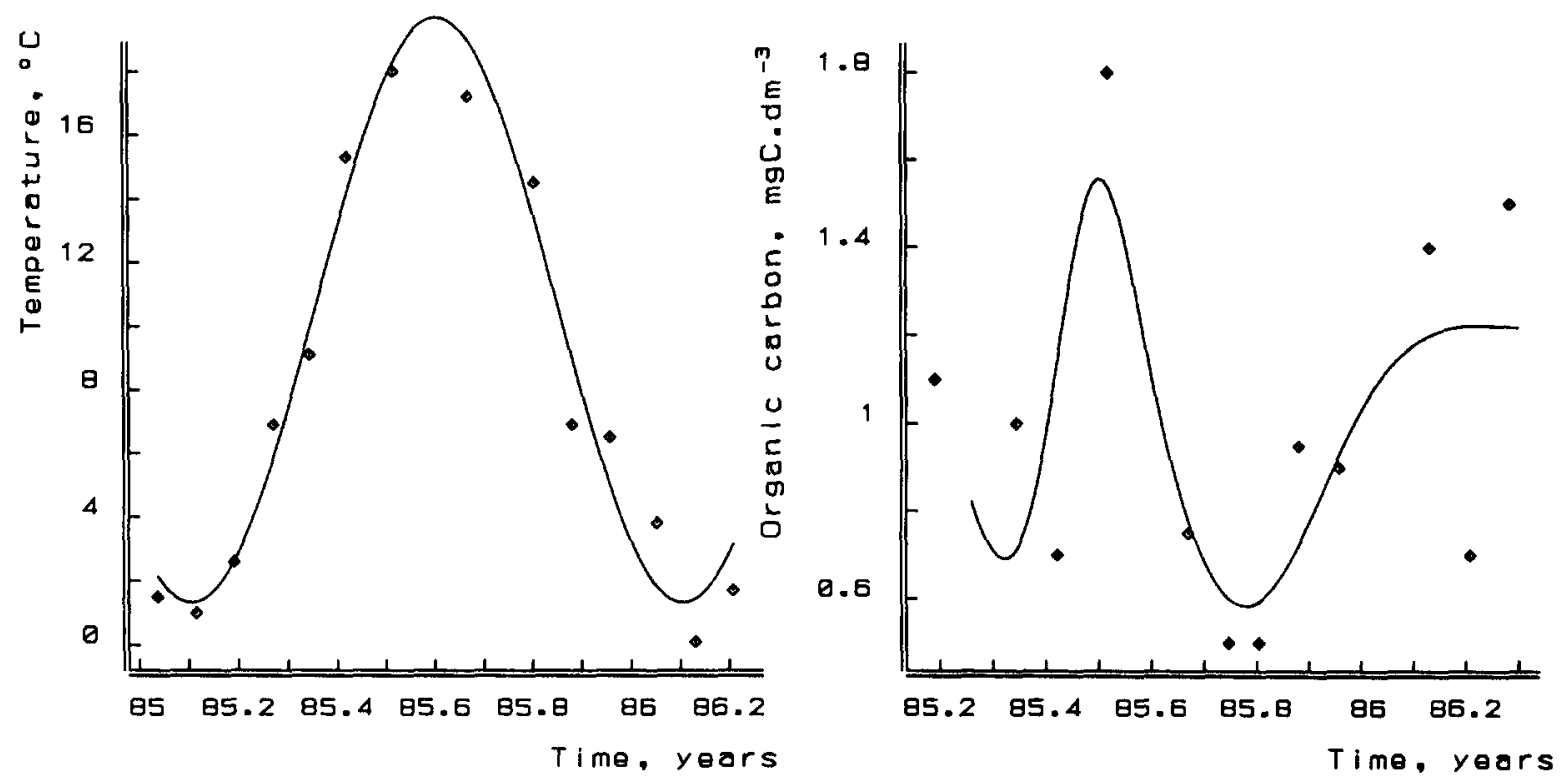

Fig. 14. Measured temperatures (left) and POC concentrations (right) in the Oosterschelde estuary (near the storm-surge barrier) during 1985 and 1986. Data from the Ministry of Public Works and Transport, Tidal Waters Division. The curves are a least-squares fitted sinus and a cubic spline.

used. A length data set of $M$. edulis is chosen from available data in the Oosterschelde (Dutch Delta area). The predicted shell lengths based on the forcing functions of temperature and food are shown in Fig. 15.

The deviation of the measured shell lengths from the prediction approximately amounts to a factor of 2 . This deviation is mainly caused by the few measurements of actual food densities in the field, see Fig. 14, and the differences in food qualities between laboratory and field (STRÖMGREN \& CARY, 1984). The energy content of algae cultured in the laboratory is generally lower than of those grown in the field. It is difficult to mimic the nutritive quality of POM in the laboratory unless fresh seawater is used. Values of the saturation constant $K$ and the energy conductance $v$ are affected by differences in food quality. When a free fit of these parameters is allowed, the length growth curve fits satisfactorily with the measured shell lengths. The adjusted parameter value for the saturation constant $K$ is 1.69 (SD 0.628 ) $\mathrm{mg} \mathrm{POC. \textrm {dm } ^ { - 3 }}$ (which is equivalent to $4.23 \mathrm{mg} P O M \cdot \mathrm{dm}^{-3}$ ) and for the energy conductance $v$ is 0.59 (SD 0.07) $\mathrm{mm} \cdot \mathrm{d}^{-1}$ at $15^{\circ} \mathrm{C}$.

\section{REPRODUCTION AND SPAWNING}

SEED (1969a) reports lengths of fully mature mussels of 6-7 mm in areas of rapid growth and lengths of 2 $\mathrm{mm}$ in areas of exceptionally slow growth. KAUTSKY (1982a) reports that maturity in the slowly growing Baltic $M$. edulis is reached at sizes smaller than 6 $\mathrm{mm}$. PILAR-AGUIRRE (1979) observed lengths of fully mature mussels of $35 \mathrm{~mm}$ on the Spanish coast. ZONNEVELD \& KOOIJMAN (1989) observed that the size at first maturity in the pond snail L. stagnalis depends on day-length. Simultaneous changes in growth and

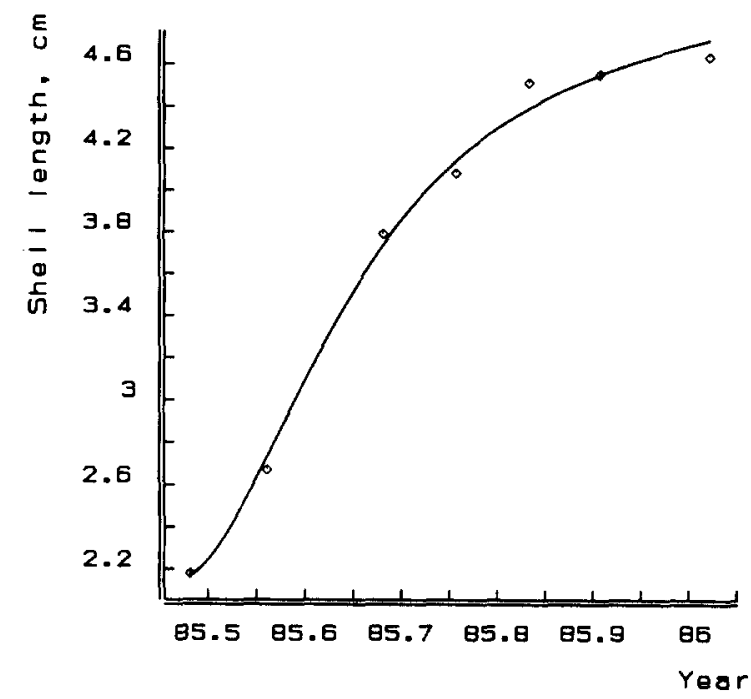

Fig. 15. Fitted shell lengths in the Oosterschelde estuary during 1985 and 1986 based on measured temperature and POC concentration. Data from the Ministry of Public Works and Transport, Tidal Waters Division. The predicted parameters based on laboratory results were $K=0.96 \mathrm{mg} \mathrm{POC \cdot \textrm {dm } ^ { - }}$ $3, v_{15}=0.23 \mathrm{~mm} \cdot \mathrm{d}^{-1}, g=1.03$ and $m_{15} g=0.0052 d^{-1}$. The deviating least-squares estimated parameters were $K=1.15$ (SD $0.38) \mathrm{mg} \mathrm{POC} \cdot \mathrm{dm}^{-3}$ and $v_{15}=0.59$ (SD 0.07$) \mathrm{mm} \cdot \mathrm{d}^{-1}$. 
reproduction could be used to deduce that day length only affects the partition coefficient $\kappa$ and so the energy available for maturation.

$M$. edulis has a pronounced annual cycle for gametogenesis with one or several spawnings in spring and summer (BAYNE, 1976). The annual cycle is usually described by discrete stages of gonad development, viz. resting stage, the ripe gonad and the spawning gonad. Observations by ZANDEE et al. (1980) and PIETERS et al. (1980) showed that energy investment into spawning is a continuous process. They found that the lipid level in mantle tissues, where the gonads are located, increases steadily after spawning. Total lipid accounts for up to $30 \%$ of the egg dry weight (PIETERS et al., 1980).

BAYNE et al. (1975) carried out experiments with labelled ${ }^{14} \mathrm{C}$ to measure carbon incorporation in mantle tissue of mussels fed a low and high ration (nongrowing and growing mussels, respectively). Their results show that more ${ }^{14} \mathrm{C}$ was transferred to the eggs at low than at high rations. This is to be expected on the basis of the DEB model, which assumes an energy drain to reproduction, even under non-growth conditions. Mussels in prolonged nongrowth conditions continued to develop new gametes, but some regression and resorption occurred in conditions of severe stress (BAYNE et al., 1978). When gametogenesis is at an early stage, BAYNE et al. (1982) found that carbohydrates in the mantle connective tissue are reallocated for routine metabolism. When the development is advanced, however, the reallocation does not occur.

The ration level of adults is apparently important for the condition of their offspring. BAYNE et al. (1975) observed that larvae developed from the gametes of adults fed a low ration had a lower growth rate than larvae from well fed adults. This is qualitatively consistent with the DEB model (KOOIJMAN, 1986c).

Somatic production has an optimum at an intermediate age of the mussel while gonadic production increases with increasing age (BAYNE \& WORRALL, 1980; THOMPSON, 1984; RODHOUSE et al., 1986). The DEB model implies that, at constant food density, the maximum body growth occurs at $V_{\infty} 8 / 27$ (KOOIJMAN, 1986a).

Fig. 16 shows the data and the curves fitted on the basis of the DEB model for three populations, in Stony Brook Harbour, New York (USA) (RODHOUSE et al., 1986), and in the Lynher and Cattewater estuaries, Morecombe Bay (U.K.) (BAYNE \& WORRALL, 1980). The fitted curves represent the shell length and yearly somatic and gonadic production which are fitted simultaneously with four free parameters. The trends in the data are well described by the DEB model.

The fraction $\kappa$ shows marked regional differences. The value of $\kappa$ in the British populations are 0.94 (SD 0.0067 ) and 0.99 (SD 0.0095), respectively, while the population in Stony Brook Harbour has a value of 0.71 (SD 0.050). These differences might be explained by a genetic control of fecundity as demonstrated by RODHOUSE et al. (1986), HILBISH \& ZIMMERMAN (1988) and GARDNER \& SKIBINSKY (1990).
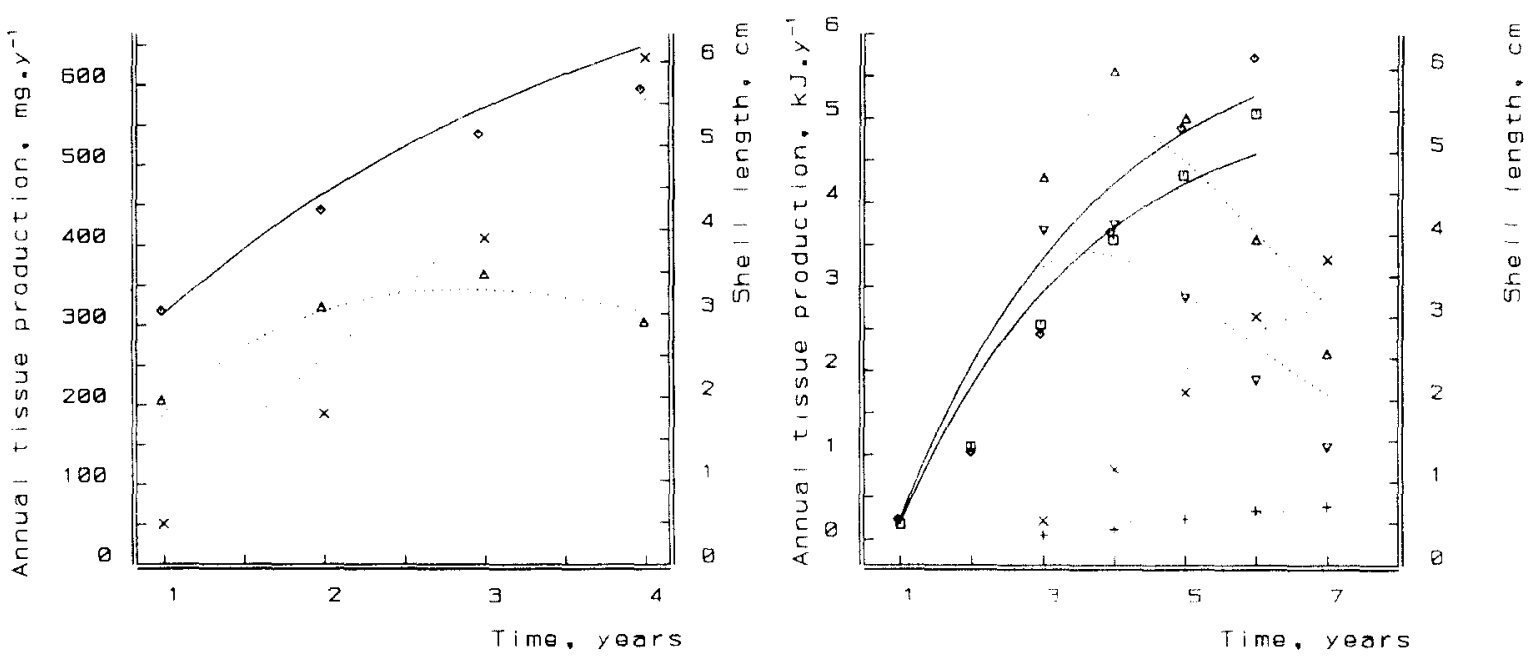

Fig. 16. Shell length $(\diamond, \square,-$,$) and production of somatic (\Delta, \nabla, \ldots)$ and reproductive tissue $\left(x_{1}+, \ldots\right)$ in three populations. Data from (left) RODHOUSE et al. (1986), and (right) BAYNE \& WORRALL (1980), on the Lynher $(\diamond, \Delta, x)$ and Cattewater $\left(\square, \nabla,+\right.$ ) sites. The estimated parameters in the left graph at presumably $15^{\circ} \mathrm{C}$ are $g=1.01(\mathrm{SD} 0.19), m g=4.2(\mathrm{SD} 0.7)$ $10^{-3} \mathrm{~d}^{-1}$ and $\mathrm{k}=0.71(0.074)$, given $v_{15}=0.23 \mathrm{~mm} \cdot \mathrm{d}^{-1}$ and $t=0.49$, a dry weight-wet weight conversion of 0.12 , with $e(0)=$ $0.46, V(0)=1 \mathrm{~cm}^{3}$ at $12^{\circ} \mathrm{C}$. For the right graph: $g=1.05$ (SD 0.073), $m g=5.0$ (SD 0.1$) 10^{-3} \alpha^{-1}$ and $\kappa_{1}=0.94$ (SD 0.01$)$ and $\kappa_{2}=0.99$ (SD 0.01) with $\epsilon_{0,1}=0.4, W_{0,1}=6.16 \mathrm{~mm}^{3}, f_{1}=0.59, e_{0,2}=0.3, W_{0,2}=4.36 \mathrm{~mm}^{3}, f_{2}=0.51$ and $v_{15}=0.19 \mathrm{~mm} \cdot \mathrm{d}^{-1}$. 


\section{DISCUSSION}

The DEB model provides a framework to describe a wide variety of physiological processes. Many data from the literature could not be used to test the theory and estimate the parameters, because essential information for their interpretation had not been provided. Differences in parameter values obtained from data taken from the literature are due to differences in experimental methods, temperature, salinities, water depths and food conditions and, to some extent, genetic variation. The following parameter estimates summarize the results for the tests against experimental data: $g=1.03, m=0.00517 d^{-1}$ and $v=0.23$ $\mathrm{mm} \cdot d^{-1}$ at $15^{\circ} \mathrm{C}$. This gives a maximal length of $13 \mathrm{~cm}$ and a maximal starvation time of 114 days for a $3 \mathrm{~cm}$ mussel. It is not known to which extent populations differ genetically in their parameter values or how the parameter values depend on environmental variables such as salinity.

The early budget studies simply describe growth as proportional to the difference between energy assimilated and used in respiration. The SFG concept conceives growth as the sum of somatic and gonadic production. These approaches do not allow for variations in internal states such as storage, which makes it impossible to accommodate results like those presented in Fig. 13. When SFG is expressed on a dry weight basis, changes in the energy buffer affect the SFG which give a false impression of actual growth in transient situations such as recovery from starvation. No concept seems so simple as body size at first glance and proved to be so difficult afterwards. The DEB model is based on volume, in which light the custom of standardization to fixed dry weights gives misleading results.

The models developed for mussel or filter feeder growth are usually based on allometric scaling relations and SFG calculations. ROSS \& NISBET (1991) modified the DEB model in order to explain the observed length and dry weight patterns in the size range 5-35 $\mathrm{mm}$, to account for sigmoid growth. They dropped the proportionality of assimilation rate to surface area. The data here tested against the DEB model gave no reason to alter the underlying assumptions. Sigmoid growth curves are expected on the basis of the DEB model when food densities and temperatures vary through the seasons.

Acknowledgements.-This study has been financially supported by the Dutch Ministry of Public Works and Transport, Tidal Waters Division, which also kindly provided data. We thank Wim van der Steen, Cor Zonneveld, Alex Ross, Daan Zandee and Brian Bayne for their critical comments.

\section{REFERENCES}

ADEMA, D.M.M., 1981. Accumulatie en eliminatie van enkele metalen door de mossel Mytilus edulis, volgens laboratorium onderzoek.-Report MT-TNO, MD-N\&E, Delft,
81/3: 1-32.

BARETTA, J. W. \& P. RUARDIJ, 1988. Tidal flat estuaries: simulation and analysis of the Ems estuary. Springer Verlag, Berlin: 1-353.

BAYNE, B.L., 1976. Marine mussels: their ecology and physiology. International Biological Programme 10. Cambridge University Press, Cambridge: 1-506.

- 1989. Measuring the biological effects of pollution: the mussel watch approach.-Water Sci. Techn. 21: 10891100.

BAYNE, B.L. \& R.C. NEWELL, 1983. Physiological energetics of Marine Molluscs. In: A.S.M. SALEUDDIN \& K.M. WILBUR. The mollusca 4. Physiology, part 1. Academic Press, New York: 407-515.

BAYNE, B.L. \& R.J. THOMPSON, 1970. Some physiological consequences of keeping Mytilus edulis in the laboratory.-Helgol. wiss. Meeresunters. 20: 526-552.

BAYNE, B.L. \& C.M. WORRALL, 1980. Growth and production of mussels Mytilus edulis from two populations.-Mar. Biol. 3: 317-328.

BAYNE, B.L., P.A. GABBOTT \& J. WIDDOWS, 1975. Some effects of stress in the adult on the eggs and larvae of Mytilus edulis L.-J. mar. biol. Ass. U.K. 55: 675-689.

BAYNE, B.L., D.L. HOLLAND, M.N. MOORE, D.M. LOWE \& J. WIDDOWS, 1978. Further studies on the effect of stress in the adult on the eggs of Mytilus edulis.-J. mar. biol. Ass. U.K. 58: 825-841.

BAYNE, B.L., A, BUBEL, P.A. GABBOTT, D.R. LIVINGSTONE, D.M LOWE \& M.N. MOORE, 1982. Glycogen utilisation and gametogenesis in Mytilus edulis L.-Mar. biol. Lett. 3: 89-105.

BAYNE, B.L., A.J.S. HAWKINS \& E. NAVARRO, 1987. Feeding and digestion by the mussel Mytilus edulis $\mathrm{L}$. (bivalvia, mollusca) in mixtures of silt and algal cells at low concentrations.-J. exp. mar. Biol. Ecol. 111: 1-22.

BAYNE, B.L., A.J.S. HAWKINS, E. NAVARRO \& I.P. IGLESIAS, 1989 Effects of seston concentration on feeding, digestion and growth in the mussel Mytilus edulis.-Mar. Biol. Prog. Ser. 55: 47-54.

BORCHARDT, T., 1985. Relationships between carbon and cadmium uptake in Mytilus edulis.-Mar. Biol. 85: 233244.

CONOVER, R.J., 1966. Assimilation of organic matter by zooplankton.-Limnol. Ocean. 11: 338-345.

EVERS, E.G. \& S.A.L.M. KOOIJMAN, 1989. Feeding, digestion and oxygen consumption in Daphnia magna. A study in energy budgets.-Neth. J. Zool. 39: 56-78.

FOSTER-SMITH, B.L., 1975a. The effect of concentration of suspension on the filtration rates and pseudofaecal production for Mytilus edulis L., Cerastoderma edule L. and Venerupsis pullastra (Montagu).-J. exp. mar. Biol. Ecol. 17: 1-22.

- $1975 \mathrm{~b}$. The effect of concentration of suspension and inert material on the assimilation of algae by three bivalves.-J. mar. biol. Ass. U.K. 55: 411-418.

GARDNER, J.P.A. \& D.O.F. SKIBINSKY, 1990. Genotype-dependent fecundity and temporal variation of spawning hybrid mussel (Mytilus) populations.-Mar. Biol. 105: 153162.

GOLDBERG, E.D., 1975. The Mussel Watch-a first step in global marine monitoring.-Mar. Poll. Bull. 6: 111.

GORHAM, W.T., 1988. The energetic and nutritional contribution of glucose and glycine taken up from natural sea water by adult marine mussels.-Mar. Ecol. 9: 1-14. HAMBURGER, K., F. MØHLENBERG, A. RANDLøV \& H.U. RIISGARD, 
1983. Size, oxygen consumption and growth in the mussel Mytilus edulis.-Mar. Biol. 75: 303-306.

HAWKINS, A.J.S. \& B.L. BAYNE, 1984. Seasonal variations in the balance between physiological mechanisms of feeding and digestion in Mytilus edulis (bivalvia, mollusca).Mar. Biol. 82: 233-240.

HILBISH, T.J. \& K.M. ZIMMERMAN, 1988. Genetic and nutritional control of the gametogenetic cycle in Mytilus edulis.Mar. Biol. 98: 223-229.

HORSTMANN, H.J., 1958. Sauerstoffverbrauch und Trockengewicht der Embryonen von Lymnaea stagnalis L.Zeit. vergleich. Physiol. 41: 390-404.

JøRGENSEN, C.B., 1976. Growth efficiencies and factors controlling size in some mytilid bivalves, especially Mytilus edulis L.: review and interpretation.-Ophelia 15: 175192.

- 1990. Bivalve filter feeding: hydrodynamics, bioenergetics, physiology and ecology. Olsen \& Oisen, Fredensborg: 1-140.

KAUTSKY, N., 1982a. Quantitative studies on gonad cycle, fecundity, reproductive output and recruitment in a baltic Mytilus edulis population.-Mar. Biol. 67: 143-160.

- $1982 \mathrm{~b}$. Growth and size structure in a baltic Mytilus edulis population.-Mar. Biol. 68: 117-133

KIØRBOE, T., F. MOHLENBERG \& O. NØHR, 1980. Feeding, particle selection and carbon absorption in Mytilus edulis in different mixtures of algae and resuspended bottom material.-Ophelia 19: 193-205.

-, 1981. Effect of suspended bottom material on growth and energetics in Mytilus edulis.-Mar. Biol. 61: 283288.

KLEPPER, O., 1989. A model of carbon flows in relation to macrobenthic food supply in the Oosterschelde estuary (S.W. Netherlands). PhD thesis Agricultural University, Wageningen, the Netherlands: 1-270.

KOOIJMAN, S.A.L.M., 1986a. Population dynamics on the basis of energy budgets. In: J.A.J. METZ \& O. DIEKMANN. The dynamics of physiologically structured populations. Lecture Notes in Biomathematics. Springer Verlag, Berlin: 266-297.

- 1986b. Energy budgets can explain body size relations. - J. theor. Biol. 121: 269-282.

- 1986c. What the hen can tell about her eggs: egg development on the basis of energy budgets.-J. Math. Biol. 23: 163-185

- 1988 . The von Bertalanffy growth rate as a function of physiological parameters: a comparative analysis. In: T.G. HALLAM, L.J. GROSS \& S.A. LEVIN. Mathematical Ecology. World Scientific, Singapore: 3-45

KOOIJMAN, S.A.L.M. \& R.J.F. VAN HAREN, 1990. Animal energy budgets affect the kinetics of xenobiotics.-Chemosphere 21: 681-693.

KOOIJMAN, S.A.L.M., E.B. MULLER \& A.H. STOUTHAMER, 1991 Microbial dynamics on the basis of individual budgets.-A. van Leeuw. 60: 159-174.

KRUGER, F, 1960. Zur Frage der Grossenabhängigkeit des Sauerstoffverbrauchs von Mytilus edulis L.- Helgol. wiss. Moeres. 7: 125-148.

LAANE, R.W.P.M., H. ETCHEBER \& J.C. RELAXANS, 1987. Particulate organic matter in estuaries and its ecological implication for macrobenthos.-Mitt. Geol. Paläon. Inst. Univ. Hamburg 64: 71-91.

LUTZ, R.A., 1976. Annual growth patterns in the inner shell layer of Mytilus edulis L._J. mar. biol. Ass. U.K. 56: 723-731.
MOHLENBERG, F. \& H.U. RIISGÅRD, 1978. Efficiency of particle retention in 13 species of suspension feeding bivalves.-Ophelia 17: 239-246.

$\ldots$, 1979. Filtration rate, using an new indirect technique, in thirteen species of suspension-feeding bivalves.-Mar. Biol. 54: 143-147.

NIELSEN, M.V., 1988. The effect of temperature on the shell length growth of juvenile Mytilus edulis L. -J. exp. mar. Biol. 123: 227-234.

NOBEL, P.S., 1991. Physicochemical and environmental plant physiology. Academic Press, San Diego: 1-635.

PAGE, H.M. \& D.M. HUBBARD, 1987. Temporal and spatial patterns of growth in mussels Mytilus edulis on an offshore platform: relationships to water temperature and food availability.-J. exp. mar. Biol. Ecol. 111: 159-179.

PIETERS, H., J.H. KLUYTMANS, W. ZURBURG \& D.I. ZANDEE, 1979. The influence of seasonal changes on energy metabolism in Mytilus edulis (L.) I. growth rate and biochemical composition in relation to environmental parameters and spawning. In: E. NAYLOR \& R.G. HARTNOLL. Cyclic phenomena in marine plants and animals. Pergamon Press, New York: 285-292.

PIETERS, H., J.H. KLUYTMANS, D.I. ZANDEE, \& G.C. CADÉE, 1980. Tissue composition and reproduction of Mytilus edulis in relation to food availability.-Neth. J. Sea Res. 14: 349-361.

PHILLIPS, D.J.H. \& P.S. RAINBOW, 1988. Barnacles and mussels as biomonitors of trace elements: a comparative study.-Mar. Ecol. Prog. Ser. 49: 83-93.

PILAR-AGUIRRE, M., 1979. Biología del mejillón (M. edulis) de cultivo de la Ria de Vigo.-Bol. Inst. Espa. Oceano. Tomo V 278: 109-159.

REMMERT, H., 1980. Arctic animal ecology. Springer Verlag, Berlin.

RICHARDSON, C.A., 1989. An analysis of the microgrowth bands in the shell of the common mussel Mytilus edulis.-J. mar, biol. Ass. U.K. 69: 477-491.

RICHARDSON, C.A., R. SEED \& E. NAYLOR, 1990. Use of internal growth bands for measuring individual and population growth rates in Mytilus edulis from offshore production platforms.-Mar. Ecol. Prog. Ser. 66: 259-265.

RIISGARD, H.U. \& F. MOHLENBERG, 1979. An improved automatic recording apparatus for determining the filtration rate of Mytilus edulis as a function of size and algal concentration.-Mar. Biol. 52: 61-67.

RIISGARD, H.U. \& A. RANDLOV, 1981. Energy budgets, growth and filtration rates in Mytilus edulis at different algal concentrations.-Mar. Biol. 61: 227-234.

RODHOUSE, P.G., C.M. RODEN, G.M. BARNELL, M.P. HENSEY, T. MCMAHON, B. OTTWAY \& T.H. RYAN, 1984. Food resource, gametogenesis and growth in Mytilus edulis on the shore and in suspended culture: Killary harbour, Ireland.-J. mar. biol. Ass. U.K. 64: 51-529.

RODHOUSE, P.G., J.H. MCDONALD, R.I.E. NEWELL, \& R.K. KOEHN, 1986. Gamete production, somatic growth and multiple-locus enzyme heterozygosity in Mytilus edulis. Mar. Biol. 80: 209-214.

ROSS, A.H. \& R.M. NISBET, 1990. Dynamic models of growth and reproduction of the mussel Mytilus edulis L.Funct. Ecol. 4: 777-787.

SCHULTE, E.H., 1975. Influence of algal concentration and temperature on the filtration rate of Mytilus edulis. Mar. Biol. 30: 331-341.

SEED, R., 1969a. The ecology of Mytilus edulis L. Lamellibranchiata on exposed rocky shores. I. Breeding and 
settlement.-Oecologia 3: 277-316.

-, 1969b. The ecology of Mytilus edulis L. ( Lamellibranchiata) on exposed rocky shores. II. Growth and mortality.-Oecologia 3: 317-350.

SPRUNG, M., 1984. Physiological energetics of mussel larvae (Mytilus edulis) I. Shell growth and biomass.-Mar. Ecol. Prog. Ser. 17: 283-293.

STRÖMGREN, T. \& C. CARY, 1984. Growth in length of Mytilus edulis $L$. fed on different algal diets. $-J$. mar. biol. Ass. U.K. 76: 23-34.

THEISEN, B.T., 1973. The growth of Mytilus edulis L. (bivalvia) from Disko and Thule district, Greenland.-Ophelia 12: 59-77.

$\ldots, 1982$. Variation in size of gills labial palps and adductor muscle in Mytilus edulis L. (bivalvia) from Danish waters. -Ophelia 21: 49-63.

THOMPSON, R.J., 1984. Production, reproductive effort, reproductive value and reproductive cost in a population of the blue mussel Mytilus edulis from a subarctic environment.-Mar. Ecol. Progr. Ser. 16: 249-257.

THOMPSON, R.J. \& B.L. BAYNE, 1972. Active metabolism associated with feeding in the mussel Mytilus edulis L.-J. exp. mar. Biol. Ecol. 9: 111-124.

,- 1974 . Some relationships between growth, metabolism and food in the mussel, Mytilus edulis.-Mar. Biol. 27: 317-326.

VAHL, O., 1972. Efficiency of particulate retention of Mytilus edulis (L.).-Ophelia 10: 17-25.

VERHAGEN, J.H.G., 1983. A distribution and population model of the mussel Mytilus edulis in lake Grevelingen. In: W.K. LAUENROTH, G.V. SKOGERBOE \& M. FLUG. Analysis of ecological systems: State of the art in ecological modelling. Elsevier Scientific, Amsterdam: 373-383.

WIDDOWS, J., 1973. The effect of temperature on the metabolism and activity of Mytilus edulis.-Neth. J. Sea Res. 7: $387-398$.

_ 1978 . Combined effects of body size, food concentra- tion and season on the physiology of Mytilus edulis.J. mar. biol. Ass. U.K. 58: 109-124.

WIDDOWS, J. \& B.L. BAYNE, 1971. Temperature acclimation of Mytilus edulis with reference to its energy budget.-J. mar. biol. Ass. U.K. 51: 827-843.

WIDDOWS, J. \& A.J.S. HAWKINS, 1989. Partitioning of rate of heat dissipation by Mytilus edulis into maintenance, feeding and growth components.-Phys. Zool. 62: 764-784.

WIDDOWS, J., P. FIETH \& C.M. WORRAL, 1979. Relationship between seston, available food and feeding activity in the common mussel Mytilus edulis.-Mar. Biol. 50: 195-207.

WINTER, J.E., 1973. The filtration rate of Mytilus edulis and its dependence on algal concentrations, measured by a continuous automatic recording apparatus.-Mar. Biol. 22: 317-328.

$\ldots$, 1978. A review on the knowledge of suspension-feeding in lamellibranchiate bivalves, with special reference to artificial aquaculture systems.-Aquaculture 13: 1 33.

WRIGHT, R.T., R.B. COFFIN, C.P. ERSING \& D. PEARSON, 1982. Field and laboratory measurements of bivalve filtration of natural marine bacterioplankton.-Limnol. Ocean. 27: 91-98.

ZANDEE, D.I., J.H. KLUYTMANS, W. ZURBURG \& H. PIETERS, 1980. Seasonal variations in biochemical composition of Mytilus edulis with reference to energy metabolism and gametogenesis.-Neth. J. Sea Res. 14: 1-29.

ZONNEVELD, C. \& S.A.L.M. KOOIJMAN, 1989. Application of a dynamic energy budget model to Lymnaea stagnalis (L.).-Funct. Ecol. 3: 269-278.

- 1993. Comparative kinetics of embryonic development.-Bull. Math. Biol. 55: 609-635.

(received 18 August 1992; accepted 16 February 1993) 